\title{
高温乾燥処理したスギ製材を用いた接合部の強度性状に関する基礎的研究 \\ 一長ホゾ込栓接合部を対象とした天然乾燥材と高温乾燥材の比較一 \\ FUNDAMENTAL STUDY ON STRENGTH BEHAVIOR OF WOODEN JOINT COMPOSED OF LUMBER OF SUGI DRIED WITH HIGH-TEMPERATURE
}

Comparison between high-temperature drying and natural drying on Mortise-tenon-joint with lumber of Sugi

藤野栄一*，桘本敬大**，津田千尋***

Eiichi FUJINO, Takahiro TSUCHIMOTO and Chihiro TSUDA

\begin{abstract}
The purpose of this study is to clarify the influence on the strength of Mortise-tenon-joint in case lumber of Sugi (Cryptomeria japonica) is dried with high-temperature. There are two kinds of Sugi that we used for this experiment, one is high-temp. drying and the other is natural drying. In order to have less dispersion of wooden characteristic, matching on the material of experiment was implemented. The target joint of experiment is Mortise-tenon-joint. The experiment is composed of 3 tests, Tensile-test on Mortise-tenon-joint, Splitting-test on foundation and Moment-resistingtest on the joint.

From the result of the above 3 tests, compared with natural one, we found that the maximum load of high-temp. drying one decreased down to about $10-20 \%$. The cause of the drop could be the inner crack due to high-temp. drying. Compared with natural drying, the load proportion of the maximum load, the result of 3 difference tests varied widely from 0.3 to 1.7 . The average of the load proportion is from 0.85 to 0.9 .
\end{abstract}

Keywords : Cryptomeria japonica, High-temperature drying, Mortise-tenon-joint, Tensile-test, Splitting-test, Moment-resisting-test スギ，高温乾燥，長ホゾ込栓接合，引張試験，割裂試験，モーメント抵抗試験

\section{1 はじめに}

近年、国内のスギ製材の乾燥方法については、乾燥温度の最高を $100^{\circ} \mathrm{C}$ 以上とする高温乾燥が主流である。高温乾燥の乾燥スケジュー ルがスギ製材の表面割れや内部割れに及ぼす影響については既に多 くの研究 ${ }^{1)}$ が行われてきており、これらの成果をもとに、材面の表 面割れを無くしかつ内部割れの発生を抑制する推奨乾燥スケジュー ルがマニュアル 2) として公表されている。しかしながら、同マニュ アルにも示されているように、推奨する乾燥スケジュールを適用し た場合であっても、製材の材端部については内部割れを抑制できな いのが実状のようである。

高温乾燥処理により製材に発生する内部割れが製材の強度性状に 及ぼす影響についても、既に多くの研究 ${ }^{3)}$ が行われてきている。そ れらによると、内部割れは製材の曲げ強度に影響を及ぼさない ${ }^{4)}$ が、
せん断強度については強度低下が認められる5 ${ }^{5)}$ とされてる。特に、 せん断強度の低下については、製材の心材部分について顕著である。 さらに、高温乾燥によるスギ製材を用いた場合の接合部の強度低 下についてもいくつかの報告がなされている。それらによると、高 温乾燥したスギ製材を用いた接合部について、材面に T 字金物を釘 留めしたホゾ接合部の曲げ試験では接合部強度に顕著な差はないこ と ${ }^{4)}$ 、敢えて内部割れを生じさせた材を使用した引きボルト接合部 については 2 割程度の強度低下が生じること ${ }^{6)}$ などが報告されてい る。また、前述の乾燥方法のマニュアルに示される推奨乾燥と意図 的に行った非推奨乾燥によるスギ製材を使用した長ホゾ込栓接合部 の引張試験より、推奨乾燥に対して非推奨乾燥は設計耐力が半分以

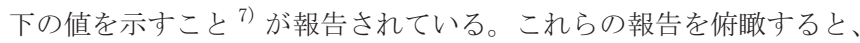
高温乾燥により製材に内部割れが生じている場合、材心近辺でせん

\footnotetext{
本論文は, 日本建築学会大会学術講演会 (北海道,2013.8)において発表した内容に加筆・修正を行ったものである。 職業能力開発総合大学校 能力開発院 Assoc. Prof., Faculity of Human Resources Development, Polytechnic University, 准教授・博士 (工学)

** 国立研究開発法人 建築研究所 材料研究グループ 上席研究員 · 博士 (農学)

***愛媛職業訓綀支援センター 上席職業訓練指導員 ·博士 (工学)
} 
断破壊が生じる接合部については、接合部耐力が低下寸る傾向が見 受けられる。このように、スギの高温乾燥による内部割れが接合部 の強度性状に及ぼす影響については、様々な視点から研究が行われ てきている。

一方、高温乾燥によるスギ製材が商品として市場に流通しはじめ た頃は、表面割れをなくすことを優先するが故に、内部割れを抑制 する適正な乾燥スケジュールが確立されていなかったことから、高 温乾燥によるスギ製材については内部割れが大きかったようである。 また、心材部分が高温による熱劣化のため繊維方向の引張強度が著 しく低下しており、伝統的な構法による在来木造住宅などを設計・ 施工寸る実務者は、高温乾燥によるスギ製材は加工時に心材が脆く 壊れることから強度が低いと認識し、一部の実務者にとっては、こ のイメージが今も根強く残っているようである。現在の高温乾燥に よるスギ製材を用いた接合部の強度性状について実務者に正しい認 識をもってもらうためには、市場に流通する一般的な高温乾燥のス ギ製材について内部割れに起因する強度低下の度合を定量的に世に 示していくことが重要である。

このような背景の下、著者らは、スギ製材を用いた込栓接合部の 強度性状に及ぼす高温乾燥処理の影響を明らかにすることを目的と して、市場に流通する高温乾燥処理したスギ製材と同様の材を用い た長ホゾ込栓接合部について、その強度低下を定量的に調べるため の実験的な研究 ${ }^{8)}$,9) を行った。

本報告は、一般的な高温乾燥スケジュールを適用したスギ製材を 用いた長ホゾ込栓接合部を対象として、高温乾燥処理が接合部の強 度性状に及ぼす影響について述べたものである。

本研究においては、高温乾燥したスギ製材を構造材として利用寸 ることを前提として、次のような(1)〜 (3)の諸点に着目して研究を進 めてきた。

(1) 一般に市場に流通寸る高温乾燥処理したスギ製材と同じ乾燥スケ ジュールを適用したスギ製材を対象として、接合部の強度低下を調 ベる。

(2) 高温乾燥処理においては、スギ製材に推奨乾燥スケジュールを適 用した場合であっても、材端部から $500 \mathrm{~mm}$ 程度までは内部割れが発 生する ${ }^{2)}$ 。製材を構造材として利用寸る場合、材端部は接合部とな ることがほとんどである。このような実状を踏まえ、適切な乾燥ス ケジュールを適用しても避けることができない製材材端部の内部割 れを対象とする。

(3) 高温乾燥処理による内部割れは製材の心材部分に多いことから、 接合部の強度低下は製材の心材部分が主として応力伝達を行う接合 方法について顕著に現れると考えられる。そこで、辺材部分が切り 落とされて心材部分で接合部の男木を構成する長ホゾ込栓接合部を 研究の対象とした。

\section{2 乾燥処理の方法およびスギ製材の諸特性值}

試験体に供する製材は、製材の乾燥表面割れの試験 ${ }^{10)}$ に使用した 長さ $2 \mathrm{~m}$ の芯持ちのスギ製材 (Cryptomeria japonica) で、2009 年 12 月 頃に埼玉県秩父近辺で伐採された長さ $6 \mathrm{~m}$ の原木から製材したもので ある。試験において製材としての物性值に大きな偏りが生じないよ うに、図 1 に示寸ように $6 \mathrm{~m}$ の製材を各 $2 \mathrm{~m}$ の製材に切断したものを 順番に組み合わせることにより、使用材料のマッチングを行ってい る。製材の乾燥方法は、天然乾燥を模擬的に再現した「(a) 常態天然 乾燥」と一般的なスギ製材の流通で適用される「(b) 高温乾燥」の 2 種類である。

常態天然乾燥は、温度 $20^{\circ} \mathrm{C}$ 湿度 $65 \%$ の恒湿恒温槽にて約 50 日養 生した後、別の試験のために長ホゾおよび貫穴の加工を行い、再度、 恒湿恒温槽にて約 2 年間常態天然乾燥を継続したものである。高温 乾燥は、図 2 に示寸乾燥スケジュール（最高温度 $120^{\circ} \mathrm{C}$ 、乾燥時間 200 時間）にて高温乾燥処理を施したもので、高温乾燥は JAS 認定工 場にて行った。本高温乾燥のスケジュールは、乾燥初期に最高温度 $120^{\circ} \mathrm{C}$ にる 22 時間の高温セットの後、徐々に温度を下げていくも ので、文献 1）に示されるスギ製材の推奨乾燥条件に類似した乾燥ス

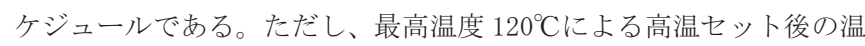
度が $100^{\circ} \mathrm{C}$ を超えている点については、乾燥スケジュールが推奨乾燥 条件とは若干異なる。高温乾燥処理後は、常態天然乾燥と同様に温 度 $20^{\circ} \mathrm{C}$ 湿度 $65 \%$ の恒湿恒温槽にて養生し、途中、別の試験のために 長ホゾおよび貫穴の加工を行っている。図 3 に、常態天然乾燥およ び高温乾燥を行った製材について、製材切断面の乾燥割れの様子を 示す。表 1 には、製材の密度、平均年輪幅および、含水率が示して ある。

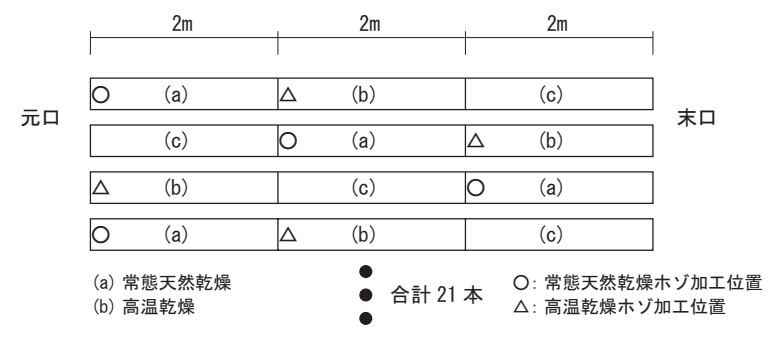

図 1 試験体の採取における製材のマッチング

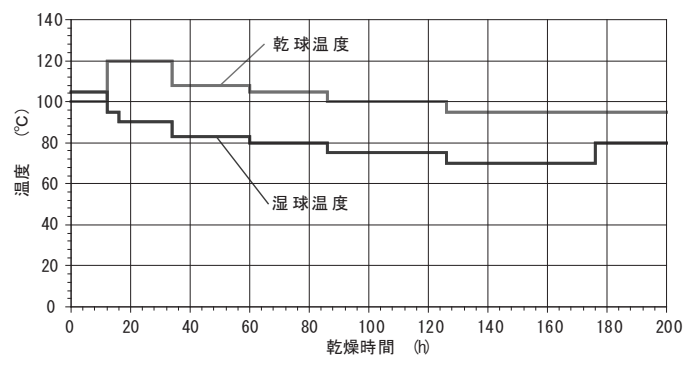

図 2 高温乾燥処理の乾燥スケジュール

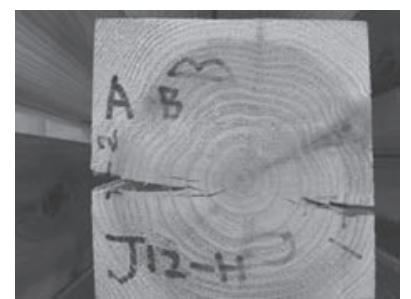

常態天然乾燥

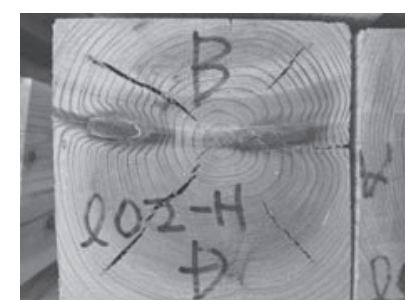

高温乾燥
図 3 乾燥割れ（製材切断面）

表 1 乾燥方法別の製材の諸特性值

\begin{tabular}{|c|c|c|c|c|}
\hline 乾燥方法 & $\begin{array}{c}\text { 密度 } \\
\left(\mathrm{kg} / \mathrm{m}^{3}\right)\end{array}$ & $\begin{array}{c}\text { 平均年輪幅 } \\
(\mathrm{mm})\end{array}$ & $\begin{array}{c}\text { 含水率 } \\
(\%)\end{array}$ & 本数 \\
\hline 常態天然乾燥 $(\mathrm{O})$ & 421 & 4.50 & 11.1 & 21 \\
\hline 高温乾燥 $(\triangle)$ & 417 & 4.75 & 8.1 & 21 \\
\hline
\end{tabular}




\section{3. 試験概要}

本研究において対象とした接合部は、前述の通り、製材の心材部 分で主たる応力伝達を行う長ホゾ込栓接合部である。長ホゾ込栓接 合部については、柱の引抜き力や曲げモーメントに対しての抵抗が 期待できることから、この 2 つの力に対しての接合部の性能につい て、スギ製材の高温乾燥処理の影響を調べる。

柱の引抜き試験については、柱ホゾの込栓部からの端抜け破壊、 土台の込栓位置における割裂破壊および、込栓の曲げせん断破壊の 3つの破壊モードにより荷重低下が生じる。また、込栓の位置や断 面寸法等によりその破壊モードが変化することが、既往の研究 ${ }^{11)}$ か ら知られている。そこで、本研究においては、スギ製材の高温乾燥 処理と天然乾燥の相対的な強度差を調べることに主眼をおき、柱ホ ゾ込栓部の端抜け抵抗性能と土台の割裂抵抗について、それぞれ別々 に高温乾燥処理の影響を調べる。具体的には、柱ホゾ込栓部の端抜 け抵抗性能については、鋼製の込栓を用いて長ホゾ先端部の込栓の 端抜け破壊を生じさせる試験（4 章）を行った。また、土台の割裂抵 抗性能についても、鋼製の込栓を用いて土台の割裂破壊を生じさせ る試験（5 章）を行った。

長ホゾ込栓接合部についてのモーメント抵抗試験（6 章）について は、込栓の破壊による強度低下が生じないように込栓断面を $18 \mathrm{~mm}$ 角 とし、込栓自体の破壊が接合部強度に影響を及ぼさない仕様として、 柱および土台を組み合わせた状態で試験を行った。

\section{4 長ホゾ込栓接合部の引抜き試験}

\section{1 試験体}

試験体の形状は、図 4 に示寸断面寸法 $120 \mathrm{~mm} \times 120 \mathrm{~mm}$ 、長さ約 500 mmで、スギの製材を柱として使用することを想定し、長ホゾに込栓 穴（18 mm角）を加工したものである。長ホゾの断面寸法は $30 \mathrm{~mm} \times$ $90 \mathrm{~mm}$ で、長さは $117 \mathrm{~mm}$ とした。込栓穴の位置は、柱胴付き面から 60mm（土台の高さ方向の中心）に込栓の端が位置するようにした。

\section{2 試験方法}

図 5 に示寸ように鋼製の治具と M12 の長ボルトを用いて試験体を 試験機に固定し、長ホゾの込栓穴に鋼製の込栓を挿入して、これを 上方に引張ることにより加力を行った。荷重は試験機のロードセル (容量 : $50 \mathrm{kN}$ ) で測定した。また、変位は試験機のクロスヘッドの移 動量とした。

\section{3 試験結果とその考察}

図 6 (a) および (b) に各乾燥条件について、荷重と変位の関係を示 す。また、図 7 には、乾燥条件の違いによる試験体 21 体の最大荷重 の比較が昇順に、表 2 には、最大荷重の平均值および信頼水準 $75 \%$ における $95 \%$ 下側許容限界等の值の比較が示してある。図 8 には初 期剛性の比較が、図 9 には最大荷重時の変位の比較が示してある。

図 6 (a) および (b) の常態天然乾燥と高温乾燥についての荷重と変 位の関係を比較すると、常態天然乾燥に対して高温乾燥は最大荷重 が低く、全体的に最大荷重時の変位が小さいことが看取できる。

図 7 に示寸最大荷重については、常態天然乾燥の平均值が $8.5 \mathrm{kN}$ であるのに対して高温乾燥は $6.6 \mathrm{kN}$ であり、高温乾燥は常態天然乾 燥に対して約 $20 \%$ 低い值を示していることがわかる。また、表 2 に 示寸最大荷重についての $95 \%$ 下側許容限界については、高温乾燥は $10 \%$ 低い值を示している。

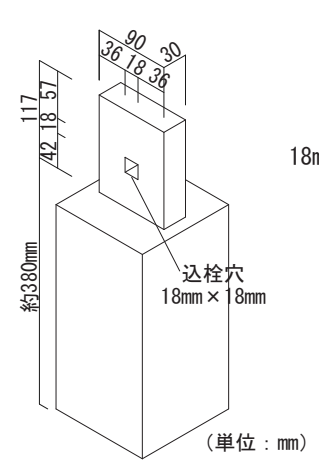

図 4 試験体

（込み栓引抜き試験）

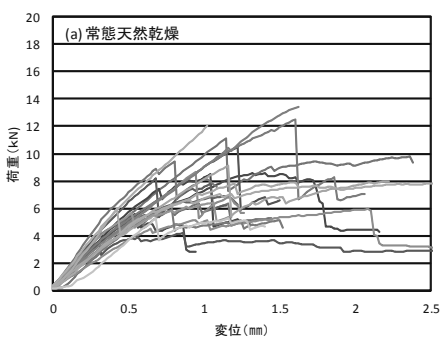

図 6 荷重と変位の関係（込栓引抜き試験）

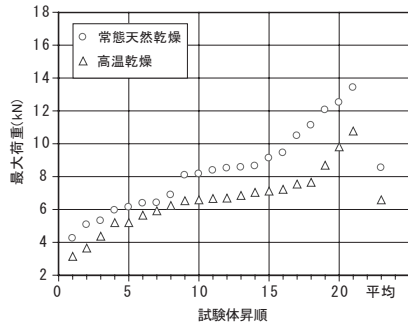

図 7 最大荷重の比較（昇順）

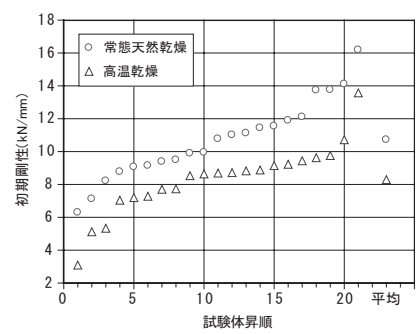

図 8 初期剛性の比較（昇順）
表 2 最大荷重の平均値等の比較

\begin{tabular}{|c|c|c|c|}
\hline ( & (a) $\mathrm{kN}$ & (b) $\mathrm{kN}$ & (b) $/$ (a) \\
\hline 最大荷重の平均 & 8.33 & 6.60 & 0.79 \\
\hline 標準偏差 & 2.47 & 1.77 & 0.72 \\
\hline 変動係数 & 0.30 & 0.27 & 0.90 \\
\hline 95\%下側許容限界 & 3.57 & 3.19 & 0.90 \\
\hline
\end{tabular}
許容限界算定時: $k=1.924$

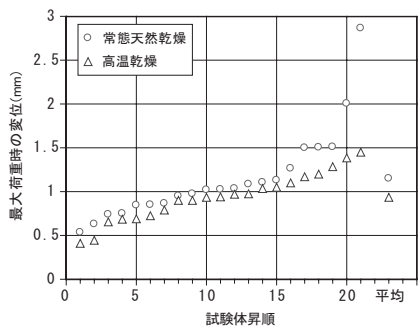

図 9 最大荷重時変位（昇順）
図 8 の初期剛性については、常態天然乾燥に対して高温乾燥は平 均で $23 \%$ 低い值を示している。

図 9 の最大荷重時の変位について、高温乾燥は常態天然乾燥に対 して $12 \%$ 低い值を示し、若干ではあるが高温乾燥は常態天然乾燥に 比べて変形追従性能が低い結果であった。

表 3 には、ホゾ木口の割れ長さの平均と図 10 の割れ面積の定義に 従って測定した割れ面積の平均が示してある。高温乾燥の材のホゾ 一本当りの割れ面積は、常態天然乾燥の約 3 倍を示している。図 11 には、最大荷重と内部割れ面積の関係が示してある。同図中には、 1 次式による近似直線と相関係数が示してある。同図より、相関係 数は約 0.45 (寄与率 $\mathrm{R}^{2}=0.2$ ）を示し、最大荷重と内部割れ面積との 間には若干の相関関係が見て取れる（最大荷重と内部割れ長さとの 間には、相関がみられなかった)。一方、く付録＞に示す、割れや節 


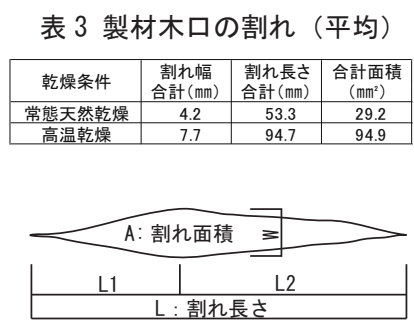

$A=W \times(L 1+L 2) \div 2(=W \times L \div 2)$

図 10 割れ面積の算定方法 図 11 最大荷重と内部割れ面積の関係

をできるだけ避けて採取した小試験片から求めたせん断強度分布に ついては、常態天然乾燥と高温乾燥に差異がほとんどない。高温乾 燥材の内部割れが無い部分については強度低下が生じていないこと から、高温乾燥のスギ製材を用いた長ホゾ込栓接合部の最大荷重が 低下寸る原因は、製材の内部割れによるものと示唆される。

\section{5.土台の割裂試験}

長ホゾ込栓接合部の引張試験における土台の割裂破壊に及ぼすス ギ製材の高温乾燥処理の影響を実験的に明らかにすることを目的と している。ここでは、土台が込栓により割裂破壊する場合を想定して、 土台単体について鋼製込栓を用いて土台の割裂試験を行った。

\section{1 試験体}

試験体は、本試験とは別の目的の試験 ${ }^{10)}$ のために長ホゾと通し穴 が加工された $2 \mathrm{~m}$ の製材より、図 12 に示すような土台の割裂試験用 の試験体を採取した。試験体の断面寸法は $120 \mathrm{~mm} \times 120 \mathrm{~mm}$ (4 寸角)、 長さは $1 \mathrm{~m}$ である。これを土台として使用することを仮定して、材長 方向中央部に長ホゾ込栓接合のホゾ穴 (幅 $36 \mathrm{~mm}$ 、長さ $90 \mathrm{~mm}$ 、通し穴) と込栓穴 (18mm 角) を加工した。ホゾ穴の位置は、既存の貫穴の影 響が最も少なくなるように、貫穴間の中央部としている。込栓穴は、 土台上端より $60 \mathrm{~mm}$ 下方（材高さ方向の中心）に込栓穴の下端が位置 するように配置した。なお、製材の表面割れは、既存の貫穴の存在 のため、ホゾ穴が加工される材上下面に集中していた。

\section{2 試験方法}

図 13 に土台の割裂試験の方法を示寸。一般的な土台一柱の接合部 の引き抜き試験を擬似的に再現するように、土台の支点間距離を 800 $\mathrm{mm}$ として、土台上端を下側にして試験体を支点上に配置する。鋼製 の込栓（断面寸法 $18 \mathrm{~mm} \times 18 \mathrm{~mm}$ ）を込栓穴に打ち込み、込栓を鋼製の 込栓加力治具により加力する。

加力は一方向単調加力とし、加力速度を $5 \mathrm{~mm} / \mathrm{min}$. とした。変位は、 鋼製込栓加力治具 (クロスヘッドの変位) と、試験体スパン中央部（試 験体側面両側）において電気式変位計（CDP-50：精度 $1 / 200 \mathrm{~mm} ） に よ$ り測定した。

\section{3 試験結果とその考察}

図 14 に、（a）常態天然乾燥および (b) 高温乾燥についての荷重と 変位の関係を例示寸る。両図の荷重一変位曲線の形状は概放同じ形 状を示し、荷重と変位の関係に差異を見出せない。

図 15 には、各乾燥条件について、試験体 21 体の最大荷重が昇順 に示してある。また、表 4 には、最大荷重の平均值および信頼水準 $75 \%$ における $95 \%$ 下側許容限界等の比較が示してある。

最大荷重については、常態天然乾燥の平均值が $17.86 \mathrm{kN}$ であるの

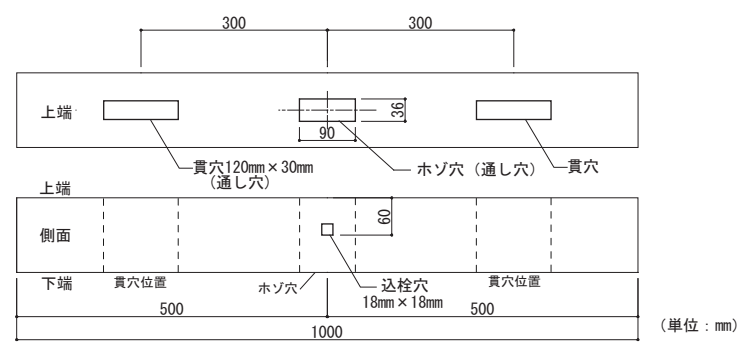

図 12 試験体（土台割裂試験）

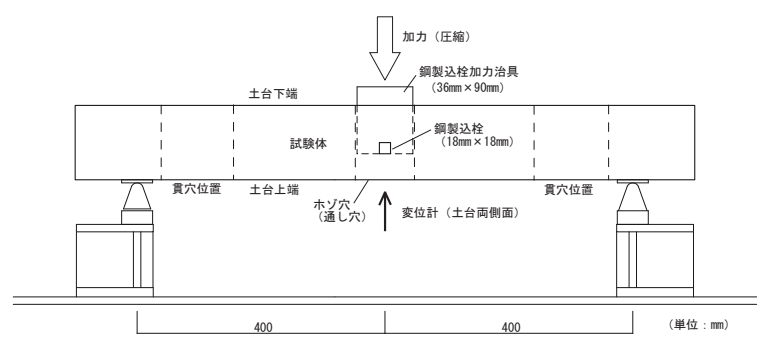

図 13 試験方法（土台割裂試験）
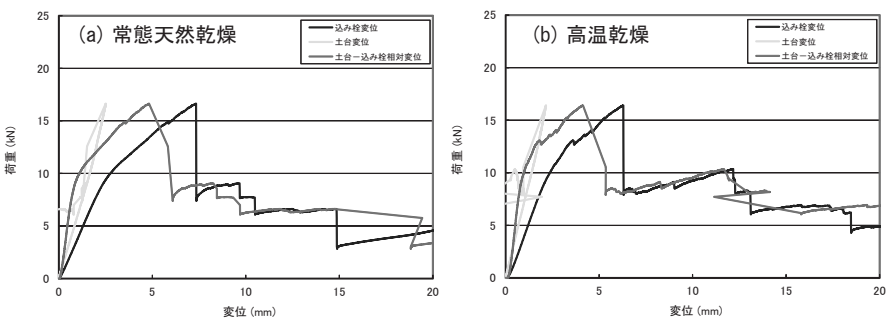

図 14 荷重と変位の関係（土台割裂試験）

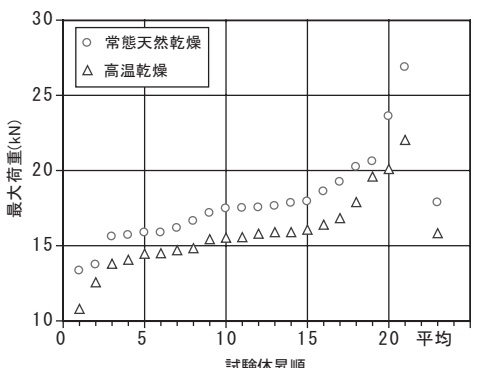

表 4 最大荷重の平均値等の比較

図 15 最大荷重の比較（昇順）

\begin{tabular}{|c|c|c|c|}
\hline 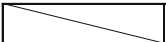 & (a) $\mathrm{kN}$ & (b) $\mathrm{kN}$ & (b) $/$ (a) \\
\hline 最大荷重の平均 & 17.86 & 15.85 & 0.89 \\
\hline 標準偏差 & 3.01 & 2.45 & 0.81 \\
\hline 変動係数 & 0.17 & 0.15 & 0.92 \\
\hline 95\%下側許容限界 & 12.07 & 11.14 & 0.92 \\
\hline
\end{tabular}

に対して高温乾燥は $15.85 \mathrm{kN}$ であり、高温乾燥処理を施した製材は 常態天然乾燥に対して約 10\% 低い值を示していることがわかる。95\% 下側許容限界の值についても、同様に約 10\% 低い值を示している。 土台の割裂試験の破壊の過程としては、(1)土台の弾性曲げ変形と 込栓位置の弾性めり込み変形、(2)込栓位置の塑性めり込み、(3)込栓 下部位置での土台の割裂、(4)込栓より下部の土台の曲げ破壊、(5)割 裂破壞の割れの繊維方向への進展の順序であった。破壞の過程およ び破壊性状について、乾燥方法の差異は看取できなかった。

\section{6 長ホゾ込栓接合部のモーメント抵抗試験}

\section{1 試験体}

試験体は、図 16 に示寸柱および横架材で構成される長ホゾ込栓接 合部である。長ホゾおよび込栓穴の形状は、長ホゾ込栓の引抜き試 験の試験体と同じ形状であり、これにホゾ穴加工した横架材を組み 合わせたものである。横架材に用いたスギ製材は、天然乾燥した断 
面 $120 \mathrm{~mm}$ 角、長さ $500 \mathrm{~mm}$ の正角材 (密度 : $370 \mathrm{~kg} / \mathrm{m}^{3}$ 、含水率 : $13.4 \%$ ) である。込栓には、シラカシ（密度 : $840 \mathrm{~kg} / \mathrm{m}^{3}$ 、含水率 : $10.2 \%$ ) を 用いた。

\section{2 試験方法}

図 17 に示寸ように、試験機に溝型鋼を用いて製作した反力フレー ムを取付け、これに試験体を設置した。試験体の変位は、図中の(1) 〜 (4)で測定した。加力モーメントは、ロードセルの荷重に加力距離 $0.41 \mathrm{~m}$ を乗じた值とし、回転角は変位計(1)おび(2)より求めた。加力 方法は回転角が 1/450rad. 〜 1/10rad. の範囲で正負交番繰返し加力 とした。

\section{3 試験結果とその考察}

図 18 に常態天然乾燥の製材を用いた試験体についてのモーメント と回転角の関係を例示する。図 19 に最大モーメント（正負の最大モ一 メトの絶対值の大きい方の值）の比較が昇順に示してある。表 5 には、 最大モーメントの平均值および信頼水準 75\% における 95\% 下側許容 限界等の值が示してある。図 20 に初期剛性（正側の回転剛性）の比 較が昇順に示してある。また、図 21 には、全 21 体の試験体について、 最大モーメントを記録した加カループごとに、その発生の度数（試 験体数) が示してある。

最大モーメントについては、常態天然乾燥に対して高温乾燥は $16 \%$ 低い值を示しており、引抜き試験と同様の強度低下の傾向を示 した。最大值についての 95\% 下側許容限界については、高温乾燥は 40\%近く低い值を示している。これは、高温乾燥の試験体の最大モー メントの值が、他に比べてばらつきが大きいことに起因するもので ある。また、初期剛性については、常態天然乾燥に対して高温乾燥 は $11 \%$ 高い值を示した。

最大モーメントを示した加力ループの回転角は、常態天然乾燥に ついては土1/30 rad. 時が最も多いのに対して、高温乾燥については 土1/50rad. が最多である。最大モーメント発現時の回転角は、高温 乾燥処理を施したスギ製材を用いた場合の方が常態天然乾燥よりも 小さいことがわかる。この最大モーメント発現時の変形性能の傾向 は、長ホゾ込栓接合部の引抜き試験の結果と同じである。

\section{7 最大荷重の荷重比の分布}

常態天然乾燥と高温乾燥の 2 種類の乾燥方法について、同じ原木 から採取した製材で構成した試験体毎に、最大荷重の荷重比（常態 天然乾燥に対する高温乾燥の比）の分布を考察する。図 22 には、最 大荷重について常態天然乾燥に対寸る高温乾燥の荷重比が昇順に示 してある。荷重比は、同じ製材から採取して異なる乾燥方法とした 試験体毎に算出したもので、 $4 \sim 6$ 章で示した 3 種類の試験について 示してある。

同図より、長ホゾ込栓接合部の引抜き試験については荷重比が 0.3 〜 1.7 の範囲を示しており、ばらつきが大きいことがわかる。また、 最大荷重についての荷重比が 1.0 を下回っている試験体は試験体総 数の約 $70 \%$ を占めている。

土台の割裂試験については荷重比が約 $0.6 \sim 1.2$ の範囲を示して おり、引抜きとモーメント抵抗の 2 試験に比べてばらつきの範囲が 小さい。荷重比 1.0 以下は試験体総数の $76 \%$ である。

モーメント抵抗試験については荷重比が $0.5 \sim 1.3$ の範囲を示し、 荷重比 1.0 以下は試験体総数の約 $70 \%$ である。

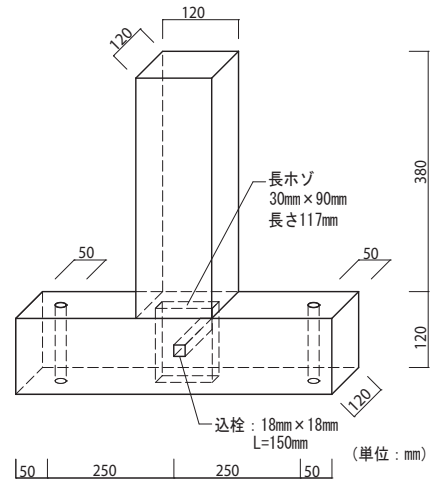

図 16 試験体（モ-メン抵抗試験）

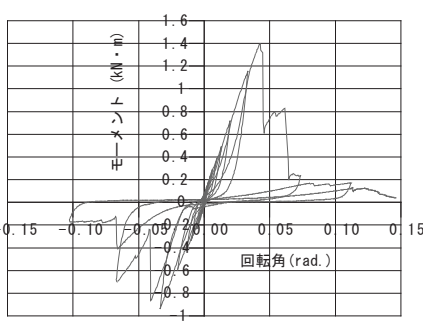

図 18 モ-メントと回転角の関係

表 5 最大モ-メント平均値等の比較

\begin{tabular}{|l|c|c|c|}
\hline & $(\mathrm{a}) \mathrm{kN} \cdot \mathrm{m}$ & $(\mathrm{b}) \mathrm{kN} \cdot \mathrm{m}$ & $(\mathrm{b}) /(\mathrm{a})$ \\
\hline 最大モ-メントの平均 & 1.42 & 1.19 & 0.84 \\
\hline 標準偏差 & 0.17 & 0.26 & 1.52 \\
\hline 変動係数 & 0.12 & 0.22 & 1.81 \\
\hline $95 \%$ 下側許容限界 & 1.10 & 0.69 & 0.63 \\
\hline
\end{tabular}

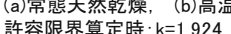

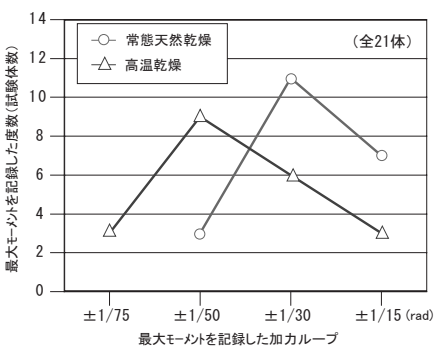

図 21 最大モ-メン発生時の加カループ に対する最大モ-メ外発生の度数

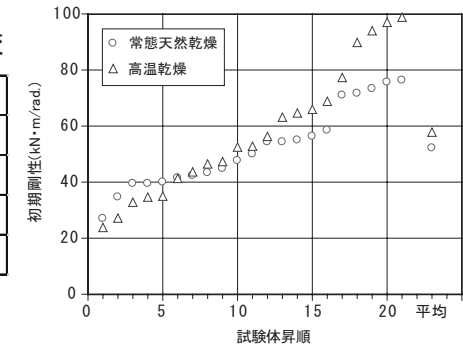

図 20 初期剛性の比較 (昇順)

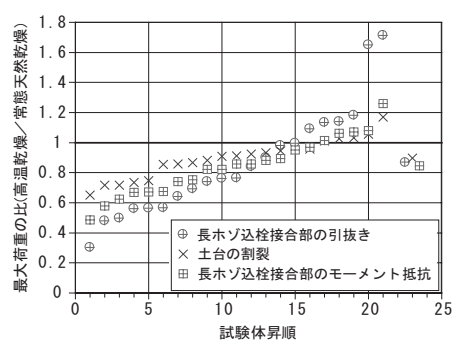

図 22 試験毎の最大荷重の荷重比 (常態天然乾燥に対する高温乾燥の比)

荷重比の分布は、 3 種類の試験において約 $0.3 \sim 1.7$ のかなり大き な範囲を示すものの、その平均值は $0.85 \sim 0.9$ の範囲であり、総じ て大きな差は認められなかった。

\section{8 まとめ}

スギ製材の高温乾燥処理が長ホゾ込栓接合部の強度性状に及ぼす 影響を、長ホゾ込栓の引抜き試験、土台の割裂試験および、モーメ ント抵抗試験について調ベた。その結果、以下の結論を得た。

（1）長ホゾ込栓部の引き抜き試験において、常態天然乾燥の製材に対 して高温乾燥処理を施したスギ製材は、約 $20 \%$ の強度低下を示した。 
また、高温乾燥材について最大荷重が低下寸る原因は、製材の乾燥 割れに起因することを示唆した。

（2）長ホゾ込栓接合部の土台の割裂試験において、高温乾燥処理を施 したスギ製材は常態天然乾燥の製材に対して、約 $10 \%$ の強度低下を 示した。

（3）長ホゾ込栓接合部のモーメント抵抗試験において、常態天然乾燥 に対して高温乾燥処理を施したスギ製材は、約 15\%の強度低下を示 した。また、最大モーメントを発現する回転角は、高温乾燥処理を 施したスギ製材を用いた場合の方が天然乾燥よりも小さい。

（4）常態天然乾燥に対する高温乾燥の最大荷重の荷重比は、3 種類の 試験について $0.3 \sim 1.7$ の範囲を示した。荷重比にはばらつきが大 きいものの、その平均値は $0.85 \sim 0.9$ の範囲であり、3 種類の試験 で大きな差はない。

\section{謝辞}

本研究の実験は、当時、職業能力開発総合大学校東京校専門課程 建築科に在籍した清水翼くんと志村綾郁さんの両氏が精力的に取り 組んだものです。また、本論文の執筆に際しては、職業能力開発総 合大学校教授松留㯖一郎先生並びに同校准教授定成政憲先生に助言 いただきました。ここに記して感謝の意を表します。さらに、本実 験の一部は、文献 8) の「伝統的構法の設計法作成及び性能検証実験」 検討委員会（委員長：鈴木祥之）において行われたものです。ここ に記して、関係各位に感謝の意を表します。

\section{参考文献}

1) 吉田孝久：木材の高温乾燥研究の変遷一高温高湿スケジュールから高温低湿 スケジュールヘー，木材工業 Vol.63, No. 9, pp. 400-405, 2008

2) 安全・安心な乾燥材の生産・利用マニュアル：「安全・安心な乾燥材生産技 術の開発」研究グループ, 石川県林業試験場 石川ウッドセンター, 2012.3

3) 池田潔彦，吉田孝久，黒田尚宏，信田聡，飯島泰男：針葉樹構造用製材の乾 燥と強度性能との関連性一乾燥割れと高温処理の影響を中心に一，木材工業 Vol. 64, No. 7, pp. 308-313, 2009

4) 武田孝志, 吉田孝久, 印出晃, 伊藤嘉文, 橋爪丈男, 徳本守彦 : 高温セット 法によるスギ心持ち柱材の曲げおよび接合強度，木材工業 Vol. 59, No. 7, pp. 302-309, 2004

5) 井道裕史, 長尾博文, 加藤英雄 : 乾燥に伴う内部割れがスギ製材品のせん断 強度に及ぼす影響，木材工業 Vol.60，No. 4, pp. 170-174， 2005

6) 富田守泰 : スギ平角材の強度性能に及ぼす高温乾燥を原因とする内部割 れの影響一曲げ強度及びボルト接合耐力ー, 木材工業 Vol.64, No. 9, pp. 416-422, 2009

7) 秋元星, 五十田博, 貴舩達也 : 木材の乾燥方法の違いが接合部強度に与える 影響, 日本建築学会大会学術講演梗概集, 構造III, pp. 103-104, 2013.8

8) 伝統的構法の設計法作成及び性能検証報告書 : 長期優良住宅等現実のための 技術基盤強化を行う事業, 平成 23 年度国土交通省補助事業報告書, 特定非 営利活動法人緑の列島ネットワーク，2012.3

9)藤野栄一, 桘本敬大, 津田千尋：スギ製材を用いた込栓接合部の強度性状 に及ぼす高温乾燥処理の影響, 日本建築学会大会学術講演梗概集, 構造 III , pp. 105-106, 2013.8

10）伝統的構法の設計法作成及び性能検証報告書 : 平成 21 年度国土交通省補助 事業報告書, 一般社団法人 木を活か寸建築推進協議会, 2010.3

11）渋谷泉，松留愼一郎，前川秀幸，藤田香織：木造接合部におけるほぞ差 込み栓の耐力評価法に関する実験研究, 日本建築学会構造系論文集 第 601 号, pp. 99-104, 2006. 3

\section{<付録 $>$ 小試験片による製材内のせん断強度分布の比較}

製材のせん断強度の分布を調べるために、製材より切り出した 小試験片を対象として、簡易的なせん断試験を行った。試験片の 形状は、高さ $30 \mathrm{~mm}$ 、幅 $30 \mathrm{~mm}$ 、長さ $120 \mathrm{~mm}$ の小試験片で、図 A1 (a) および（b）に示すように $120 \mathrm{~mm}$ 角正角材から割れや節をできるだ け避けて採取した。正角材の辺材部から採取した試験片をF、正角 材の心材部から採取した試験片をI とし、それぞれ木口から $10 \mathrm{~mm} 、$ $30 \mathrm{~mm} 、 50 \mathrm{~mm}$ の位置で簡易的なせん断試験を行った。試験方法は、 JIS Z 2101 に準じて、図A2 に示すような試験治具を用いてせん断 試験を行った。

図 A3 (a) には常態天然乾燥、(b) には高温乾燥について、せん断 強度の分布を示す。乾燥割れがほとんど無い小試験片についてのせ ん断強度の值は、常態天然乾燥に対して高温乾燥は平均で約 $5 \%$ 高 い值を示寸結果であった。
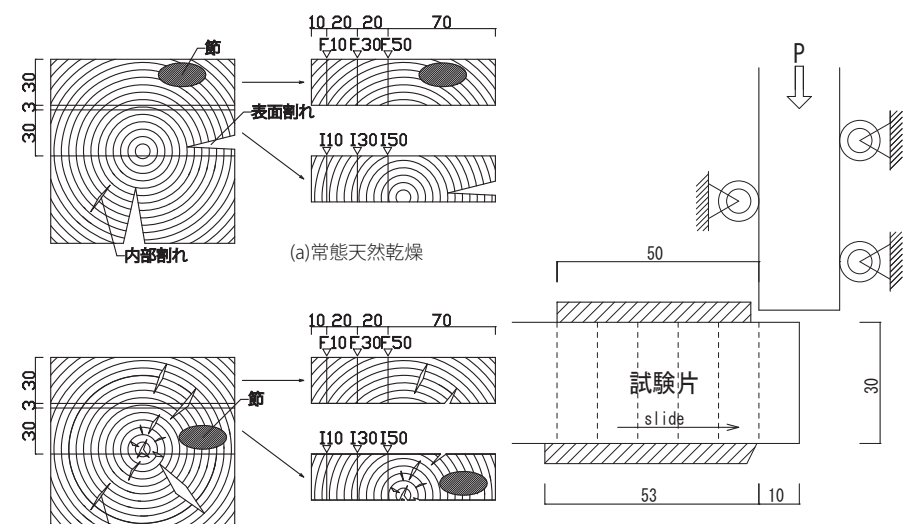

図 A2 せん断試験の方法

図 A1 せん断試験用小試験片の採取方法

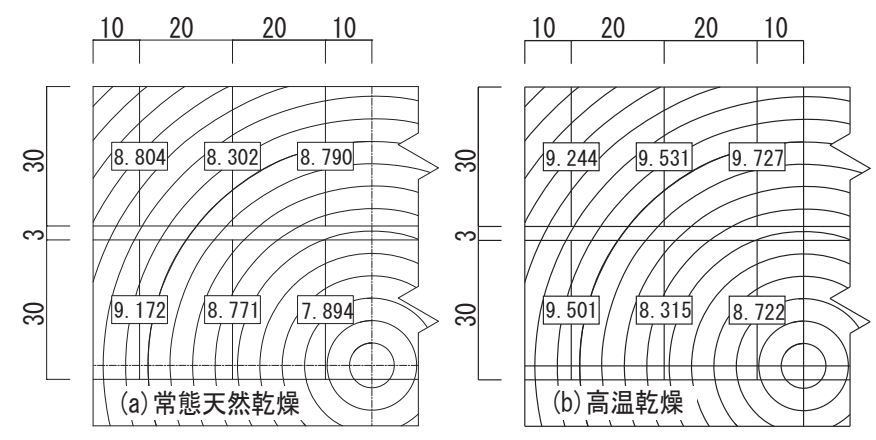

図 A3 常態天然乾燥材と高温乾燥材のせん断強度の分布 $\left(\mathrm{N} / \mathrm{mm}^{2}\right)$ 


\title{
FUNDAMENTAL STUDY ON STRENGTH BEHAVIOR OF WOODEN JOINT COMPOSED OF LUMBER OF SUGI DRIED WITH HIGH-TEMPERATURE
}

Comparison between high-temperature drying and natural drying on Mortise-tenon-joint with lumber of Sugi

\author{
Eiichi FUJINO*, Takahiro TSUCHIMOTO** and Chihiro TSUDA*** \\ * Assoc. Prof., Faculity of Human Resources Development, Polytechnic University, Dr. Eng. \\ ** Chief Research Engineer, Dept. of Building Materials and Components, Building Research Institute, Dr. Agr. \\ *** Chief Vocational Training Instructor, Ehime Polytechnic Center, Dr. Eng.
}

The purpose of this study is to clarify the influence on the strength of Mortise-tenon-joint in case lumber of Sugi (Cryptomeria japonica) is dried with high-temperature. There are two kinds of Sugi that we used for this experiment, one is high-temp. drying and the other is natural drying. The way of matching is shown in Fig.1, cut the lumber $6 \mathrm{~m}$ down to $2 \mathrm{~m}$ and match them one by one. The schedule of high-temp. drying is shown in Fig.2. In order to have less dispersion of wooden characteristic, matching on the material of experiment was implemented. The target joint of experiment is Mortise-tenon-joint. The experiment is composed of 3 tests, Tensile-test on Mortise-tenon-joint, Splitting-test on foundation and Moment-resisting-test on the joint. Tensile-test on Mortise-tenon-joint is shown in chapter 4, splitting-test on foundation is chapter 5 and Moment-resisting-test on the joint is chapter 6

With our experiment, the followings have discovered.

1) On the Tensile-test, compared with natural drying, the strength of the joint with Sugi dried with a high-temperature decrease about $20 \%$, as shown in Fig.7 and Table2. We found a little correlation between the maximum load and the inner crack dimension, as shown in Fig.11. As shown in Appendix, the distribution of strength on the shear test of the specimen, there is little difference between natural and high-temp. The cause of the maximum load decrease for dried with high-temperature is considered to be due to inner crack of the material.

2) On the Splitting-test on foundation, Sugi dried with a high-temperature, the strength decrease about $10 \%$, as shown in Fig.15 and Table4.

3) On the Moment-resisting-test on Mortise-tenon-joint, the strength of the joint of Sugi dried with a high-temp. decrease about $15 \%$, as shown in Fig.19 and Table5. On the rotation angle at maximum moment, the joint of Sugi dried with a high-temp. was smaller than natural drying one, as shown in Fig.21.

4) Compared with natural drying, the load proportion of the maximum load on dried with a high-temp., the result of 3 tests showed from 0.3 to 1.7, as shown in Fig.22. The maximum load proportion varies widely. The average of the load proportion is from 0.85 to 0.9 , there is no large difference in the 3 tests. 